\title{
VESSEL-FIBRE RATIO, SPECIFIC GRAVITY AND DURABILITY OF FOUR GHANAIAN HARDWOODS
}

\author{
C. Antwi-Boasiako and E. Atta-Obeng \\ Department of Wood Science \& Technology, Faculty of Renewable Natural Resources \\ Kwame Nkrumah University of Science \& Technology, Kumasi, Ghana.
}

\begin{abstract}
Several factors affect wood durability but the influence of anatomy is scarcely studied. Vessels and fibres sampled across and along stems of Milicia excelsa (Welw.) C. C. Berg) (odum), Entandrophragma cylindricum (Sprague) Sprague (sapele), Terminalia ivorensis A. Chev. (emire) and Antiaris toxicaria Lesch. (kyenkyen) were studied to understand the relationship between their vessel-fibre ( $V-F)$ ratios, specific gravities (SGs) and durabilities. Vessels, fibres and their proportions were examined from macerates and T.S. of prepared slides. While the timbers exhibit major hardwood cell-types (e.g. vessels, fibres and parenchyma), intra-stem variability exists with more vessels and greater $V$-F ratios at the crowns and in sapwoods than at the butts and in heartwoods, unlike for fibres. Inter-specific variation also shows A. toxicaria has the greatest vessel content then $T$. ivorensis, $E$. cylindricum and $M$. excelsa, a contrary pattern for fibre contents. $V$-F ratio ranks as: $A$. toxicaria $>E$. cylindricum $>$ T. ivorensis $>M$. excelsa, while $S G s$ are higher in E. cylindricum (667) and M. excelsa (635) than in T. ivorensis (507) and A. toxicaria (505), which hardly differ from published data. Except for E. cylindricum, butts have the greatest $S G$ s. Correlations between their $V-F$ ratios and $S G$ are $R^{2}=34 \%, 84 \%, 32 \%$ and $1 \%$ respectively. Timbers with greatest vessels and $V$-F ratios but least fibres and SGs have weak relationship and very low durabilities, as in $A$. toxicaria $\left(R^{2}=1 \%\right)$. However, M. excelsa, which has the strongest $V$-F ratio and $S G$ relationship $\left(R^{2}=84 \%\right)$, is very durable.
\end{abstract}

Keywords: Cell type, durability class, macerates, paratracheal parenchyma, vessel-fibre ratio

\section{INTRODUCTION}

Wood has always served man and contributed decisively to his survival all through the development of civilization, as the raw material for several products including furniture, flooring, sleepers, dowels and bridges amid other competitive materials such as metals, cement (i.e. concrete) and plastics (Tsoumis, 1991). These functions would require understanding of wood characteristics including anatomy, specific gravity, chemistry, physico-mechanical properties and durability. Anatomically, woods from different timber species have different cell arrangements (Irvine, 1961). Within a species, the relative proportion of various cell types is consistent. However, among species and species groups (i.e. genera), various kinds of cells and properties are pronounced (Wilson and 
White, 1986). Such cell type variation and their arrangement affect timber characteristics. Hardwoods comprise at least four major cell types: fibres, vessels, longitudinal and ray parenchyma. Each may constitute $15 \%$ or more of the volume of hardwood xylem. Of these, two kinds of longitudinal cells, fibres and vessels, are common. Most conduction occurs through the specialized vessels leaving the thick-walled (highly lignified) fibres the primary function of mechanical support (Esau, 1977). Fibre applies to long, narrow cells with closed ends other than tracheids (Panshin and de Zeeuw, 1980), tapered and usually thick-walled cells of hardwood xylem (Tsoumis, 1991). Kollman and Côté (1984) also described vessel as the distinctive tracheary structure of all hardwoods referred to as a pore because, when viewed in cross section, it has a larger lumen than other cell types. They vary in size and shape depending upon the wood species and location within the growth increment of the stem. Parenchyma cells are thin-walled and rectangular, which contain protoplasm. Lateral types (called ray parenchyma) conduct sap horizontally. Notably, cell types affect wood properties including specific gravity (SG), which Haygreen and Bowyer (1996) defined as the ratio of its density to the density of water, and is also considered the single best indicator of strength and durability (Shrivastava, 1987). McDonald et al. (1995) citing, Whitmore (1973) and Wiemann and Williamson $(1988,1989)$, reported that while many species have a constant SG, some tropical wet forest trees show very large increases $(>200 \%)$ from heartwood to the sapwood. Wiemann (1990) and McDonald et al. (1995) associated the radial increase in wood SG probably with one of the following anatomical changes: increase in fibre wall thickness, decrease in fibre lumen diameter and increase in fibre frequency. SG is also generally related to the proportion of wood volume occupied by fibre relative to that occupied by vessels (Wilson and White, 1986).

The amounts of cell types also affect wood durability, specific gravity and its strength properties. For instance, the relative density of wood is most strongly influenced by the vesselto-fibre ratio, among others (Balatinecz et al, 2001). Panshin and de Zeeuw (1980) reported that the natural durability of wood is due to toxic heartwood extractives and principally its cell wall constituents (lignifications) and their relative distributions in the different cell types. They stated that wood is degradable through attack by bacteria, fungi and certain insects (e.g. termites). Thus, those with remarkably excellent, moderate or no resistance at all to bio -deterioration are termed durable, moderately and non-durable (or perishable) respectively. Properties and proportions of vessels and fibres of timbers would likely affect their SGs besides chemistry and strength. Thus, this study sought to determine the fibre-vessel properties and their relationship with SGs as well as durabilities of four Ghanaian timbers [odum (Milicia excelsa (Welw.) C. C. Berg), emire (Terminalia ivorensis A. Chev.), sapele (Entandrophragma cylindricum) (Sprague) Sprague and kyenkyen (Antiaris toxicaria Lesch.)].

\section{MATERIALS AND METHODS Preparation of wood samples for various tests}

The four hardwood species were selected from Mim, Brong-Ahafo (in the semi-deciduous forest of Ghana) based on variation in their natural durability, minimum felling rate and availability. Two discs $(30 \mathrm{~cm})$, taken from the sapwood and heartwood (near the bark and pith respectively) from the butt (i.e. diameter at breast height) and crown ( $1 \mathrm{~m}$ beneath the main branch) regions of each timber were air-dried, cut and planed into radial strips $(2 \times 2 \times 20 \mathrm{~cm})$ and air-dried to $12-14 \%$ moisture content $(\mathrm{mc})$. They were conditioned (at $25^{\circ} \mathrm{C}$ and $65 \%$ rh) and further sectioned into the required dimensions for the various tests.

\section{Determination of specific gravity}

Specific gravity was determined based on airdried weight (12-14\% mc) and volume of wood (Haygreen and Bowyer, 1996). Ten blocks $(2 \times 2 \times 5 \mathrm{~cm})$ from the sapwood and heartwood sampled from the butt and crown regions of 
each timber were weighed, made air-tight with plastic foils and their volumes determined by water displacement. The specific gravity of each stake was calculated by dividing the conditioned air-dried weight by the volume of water it displaced in the formula:

$S G=\frac{W}{(V a-V b)}$, where, $W=$ air-dried weight

of stake at $12-14 \% \mathrm{mc}, \mathrm{Va}=$ volume of water after immersion, $V b=$ volume of water before immersion.

\section{Sectioning of wood samples}

Conditioned stakes $\left(3 \mathrm{~cm}^{3}\right)$ from each stem position of each timber were first softened by boiling in water for $18 \mathrm{hrs}$. $20 \mu \mathrm{m}$-thick sections from their transverse surfaces were made from each stake (using a sliding microtome), washed in water and stained in $1 \%$ Safranin in 50\% ethanol for 10 minutes. The sections were rewashed in water and passed through a series of increasing concentration of ethanol $(30,50,70$, 95 and $100 \%$ ) for $5 \mathrm{mins}$. each to dehydrate them. The samples were then mounted in Canada balsam. All prepared slides were dried at $60^{\circ} \mathrm{C}$ overnight and observations then made under the light microscope. Fibre, vessel and parenchyma tissue proportions were determined from each sample using $\times 10$ and $\times 40$ objective and $\times 10$ eyepiece lens with a 20 -point dot grid scale placed progressively at five different positions. At each placement, the number of points covering any tissue was counted and later expressed as a percentage of the total number of points. Terminology for description of anatomical features followed the IAWA Committee's recommendations (Anon., 1989). Qualitative anatomical descriptions of the four species were represented using photomicrographs, while ANOVA and Duncan's Multiple Range Test (DMRT) were employed to evaluate the variations in quantitative anatomical and physical property (e.g. SG) among the timber species (i.e. species effect $\}$ and between the two different positions (i.e. position effect). Simple regression analysis was also employed to evalu- ate the relationship between vessel-fibre ratio and specific gravity of each timber.

\section{RESULTS}

Brief anatomical properties of the timbers

Qualitative anatomical descriptions of the four species (i.e. M. excelsa, E. cylindricum, $T$. ivorensis and A. toxicaria) are represented using micrographs in Plates 1-4 respectively. Plate 1 shows the transverse section (T.S.) of sapwood and heartwood of $M$. excelsa from its crown and butt regions, as in the other three timbers. Generally, M. excelsa has medium $(100-200 \mu \mathrm{m})$ to very large $(300 \mu \mathrm{m})$ vessels. Proportion of solitary vessels is medium with two to three radial multiples of the same size. Fibre tissue proportion is low $(21-40 \%)$ to medium (41-60\%). Axial parenchyma is paratracheal, while the ray parenchyma is narrow $(\leq$ $0.5 \mathrm{~mm}$ ) and of uniform width. T.S. of E. cylindricum (Plate 2) shows it has small $(<100 \mu \mathrm{m})$ to medium $((100-200 \mu \mathrm{m})$ vessels, solitary with 2 - 3 radial multiples, and also of the same size. Fibre proportion is low (21-40\%) to medium (41-60\%). Similarly, axial parenchyma is paratracheal, ray parenchyma uniform and narrow ( $\leq 0.5 \mathrm{~mm})$. T.S. of the T. ivorensis stem shows its vessels are medium $(100-200 \mu \mathrm{m})$ to large $(200-300 \mu \mathrm{m})$, solitary with 2 to 4 radial multiples, and of the same size. Fibre tissue proportion is low $(21-40 \%)$ to medium (41-60\%). Axial parenchyma is paratracheal (i.e. associated with pores, and of vasicentric type), ray parenchyma very narrow $(\leq 0.5 \mathrm{~mm})$ and of uniform width (Plate 3$)$. Plate 4 shows $A$. toxicaria's vessels to be large $(200-300 \mu \mathrm{m})$, their proportions being medium, 2 to 3 radial multiples and of different sizes. Fibre tissue proportion is often low (21-40\%) to medium (41$60 \%$ ). Axial parenchyma is paratracheal, ray parenchyma narrow $(\leq 0.5 \mathrm{~mm})$ and with variable widths.

\section{Variation in vessel and fibre contents}

For all the species, more fibres exist than vessels at each stem position. For vessels, $A$. toxicaria seems to have the greatest amount except at its butt sapwood, while $M$. excelsa has the 

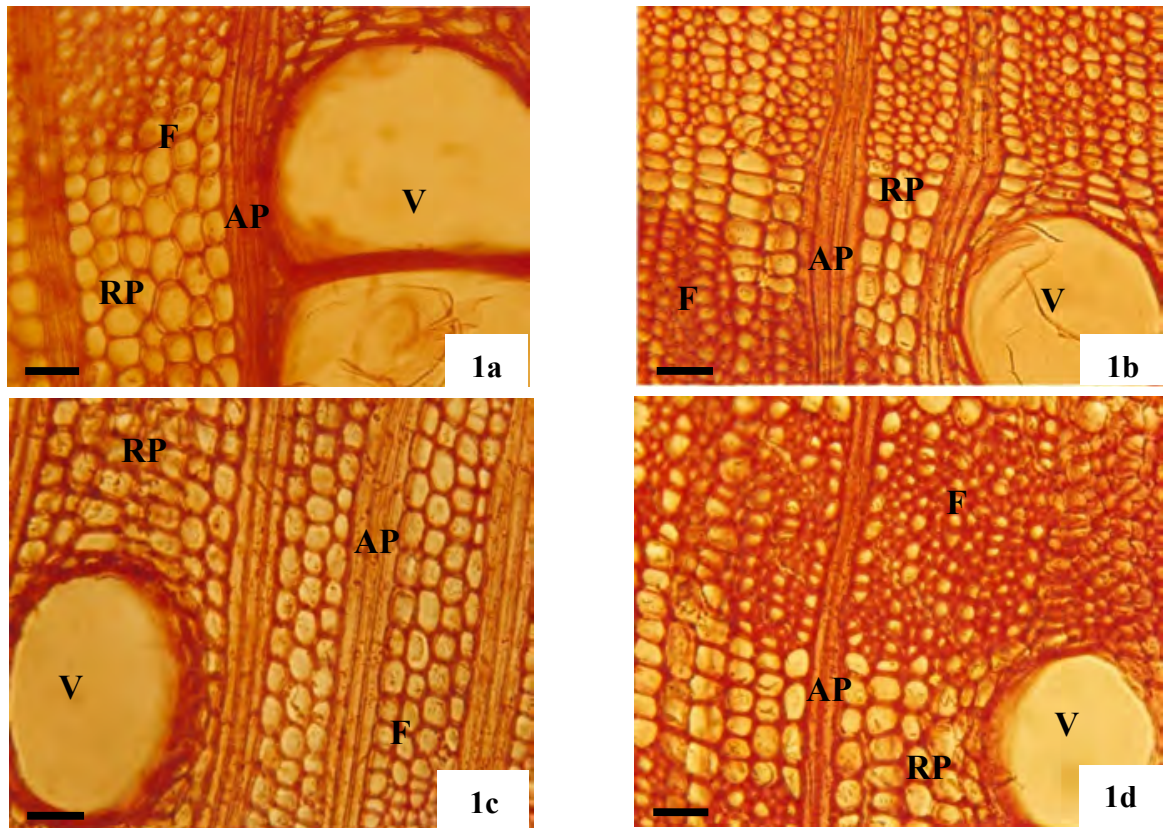

Plate 1: T.S. of Milicia excelsa stem: (a) Sapwood from crown (b) Heartwood from crown (c) Sapwood from base (d) Heartwood from base $(V=$ vessel, $A P=$ Axial parenchyma, $R P=$ Ray parenchyma, $F=$ Fibre). Scale bar $=20 \mu \mathrm{m}$.
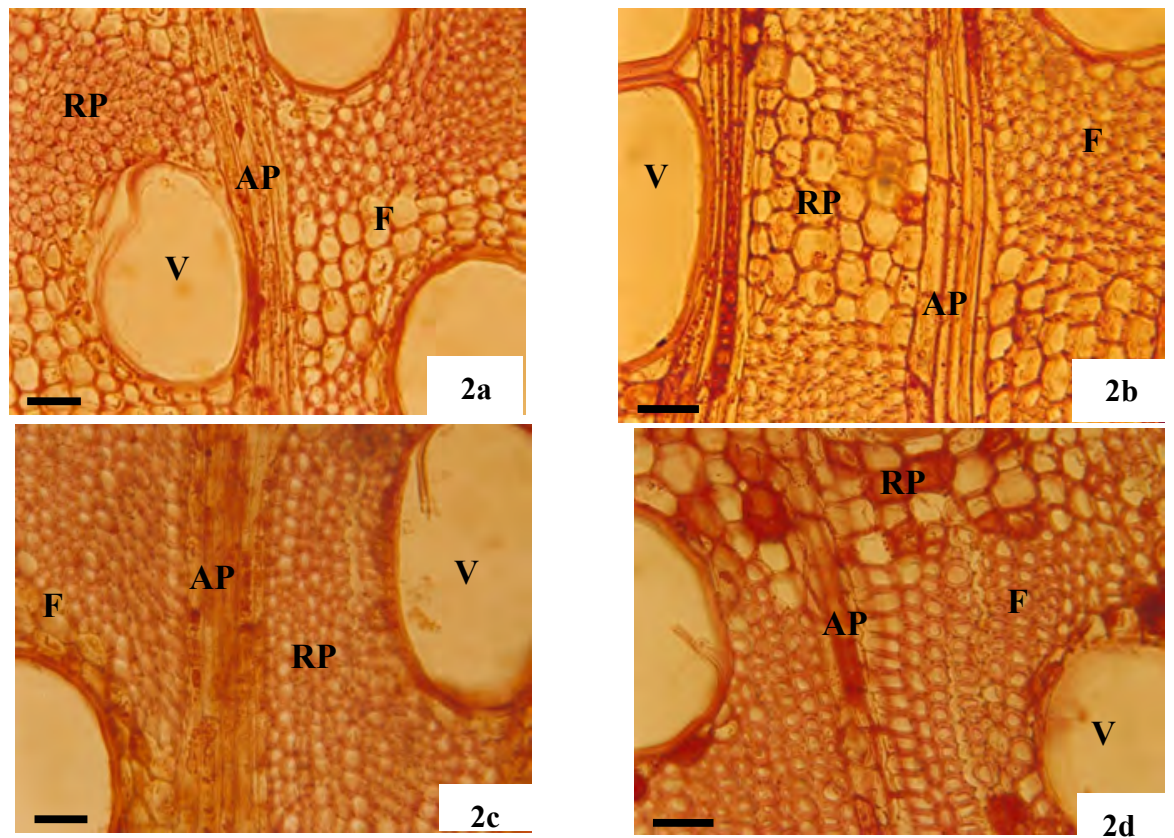

Plate 2: T. S. of E. cylindricum. (a) Sapwood from crown (b) Heartwood from crown (c) Sapwood from base (d) Heartwood from base $(V=$ vessel, $A P=$ Axial parenchyma, $R P=$ Ray parenchyma, $\mathrm{F}=$ Fibre). Scale bar $=20 \mu \mathrm{m}$. 

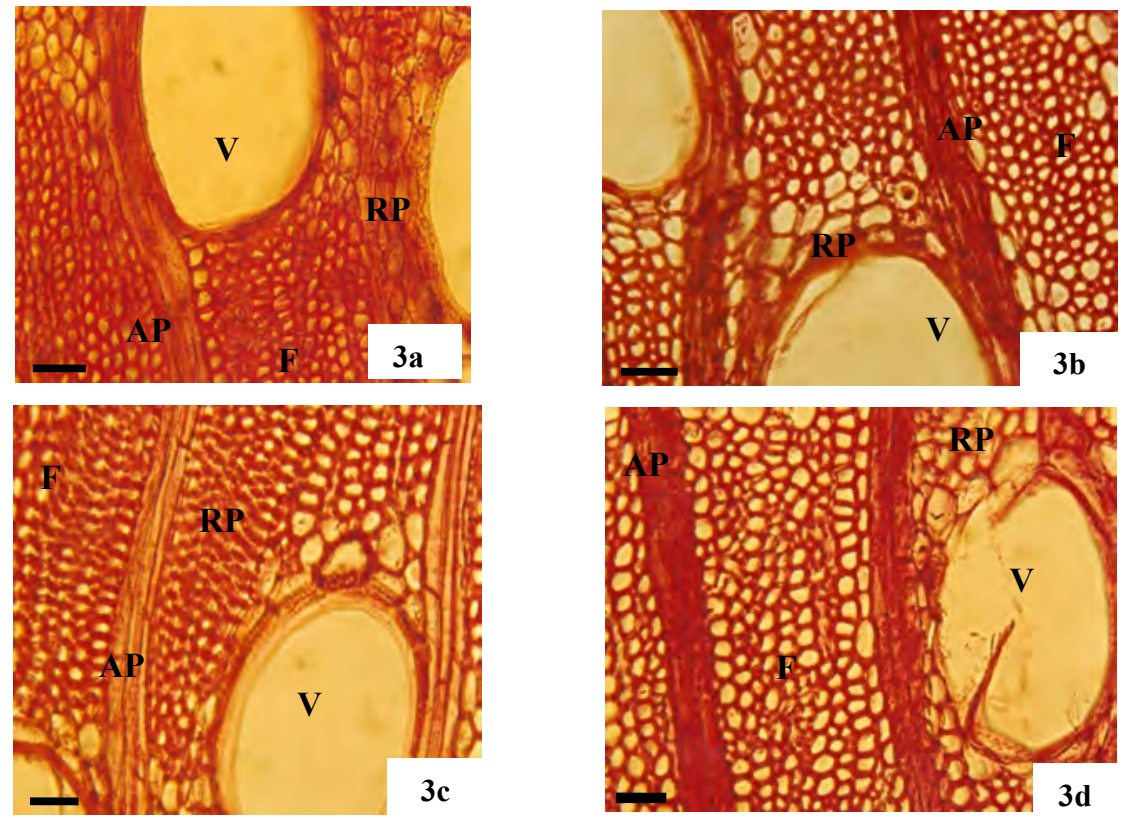

Plate 3: T.S. of T. ivorensis. (a) Sapwood from crown (b) Heartwood from crown (c) Sapwood from base (d) Heartwood from base $(V=$ vessel, $A P=$ Axial parenchyma, $R P=$ Ray parenchyma, $F=$ Fibre). Scale bar $=20 \mu \mathrm{m}$.
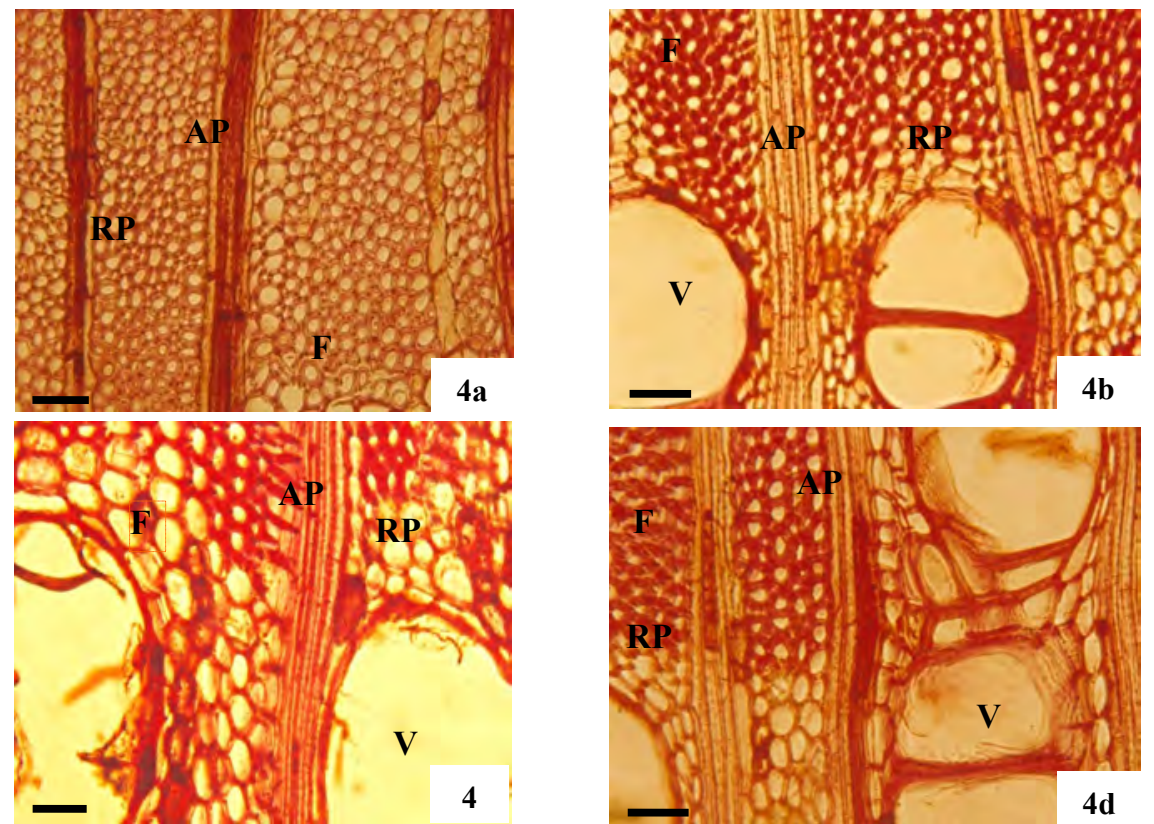

Plate 4: T. S. of A. toxicaria. (a) Sapwood from crown (b) Heartwood from crown (c) Sapwood from base (d) Heartwood from base $(\mathrm{V}=$ vessel, $\mathbf{A P}=$ Axial parenchyma, $\mathrm{RP}=$ Ray parenchyma, $\mathrm{F}=$ Fibre). Scale bar $=20 \mu \mathrm{m}$. 
least especially within its heartwood at the base (Fig. 1). Both T. ivorensis and E. cylindricum have more vessels in their sapwoods, notably at their crowns. The difference between the respective vessel contents of all the timbers is significant $(\mathrm{p}<0.05)$ (Fig. 1; Table 1). Duncan's Multiple Range Test for vessels (Table 2a) shows that the differences between vessel content of $T$. ivorensis, A. toxicaria and E. cylindricum are not significant $(\mathrm{p}<0.05)$, but these are different from that of $M$. excelsa. Axially, there is significant difference $(\mathrm{p}<0.05)$ between vessel content at the crown and butt regions of all the timbers (Table 2b). Similarly, this is so at the radial positions; vessels within the sapwoods of the timbers are more than in their heartwoods (Table 2c). With respect to fibres, $M$. excelsa's crown sapwood recorded the greatest amount with those in A. toxicaria heartwood at the crown being the least. $E$. cylindricum recorded the highest in its heartwood but $T$. ivorensis in its butt sapwood. The differences in the fibre content among the four timbers are also significant $(\mathrm{p}<0.05)$ (Table 3 ) with M. excelsa having the greatest (Table 4a). Along each bole, there is no difference between fibre contents for the crown and butt regions (Table 4b). At their radial stem positions (i.e. for sapwood and heartwood), no difference exists for the fibre contents (Table 4c). In all cases, a decrease in the amount of vessels is accompanied by an increase in fibre content.

Vessel-fibre ratio and specific gravity for each timber

$\mathrm{V}-\mathrm{F}$ ratio is greatest in the sapwood of E. cylindricum than in its heartwood, especially more at its butt than crown (Fig. 2). The difference between their $\mathrm{V}-\mathrm{F}$ ratios is significant $(\mathrm{p}<0.05)$. However, no difference exists between V-F ratios of the heartwoods and also between those of the sapwoods irrespective of the position

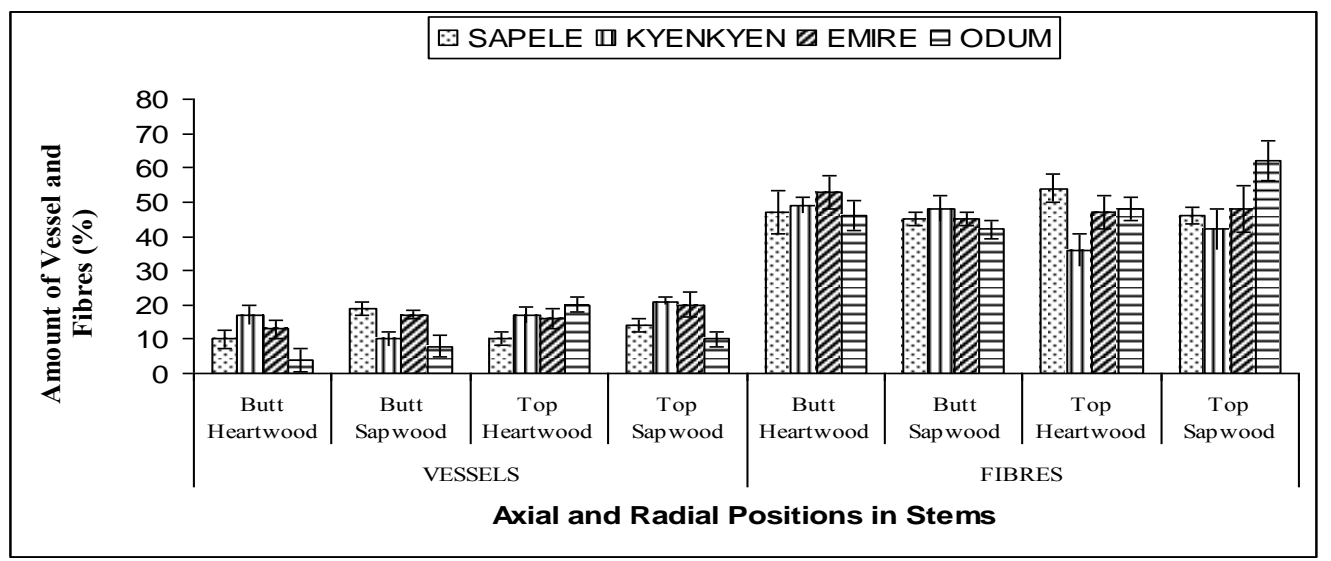

Bars $=$ Standard errors

Fig. 1: Vessel and fibre contents among the four species

Table 1: ANOVA for vessel contents for the timber species

\begin{tabular}{lccccc}
\hline \multicolumn{1}{c}{ Source } & $\begin{array}{c}\text { Degree of } \\
\text { Freedom }\end{array}$ & Sum of Squares & Mean square & F-value & Pr $>$ F \\
\hline Model & 15 & 1770 & 118 & 3.78 & $<0.0001$ \\
Error & 64 & 2000 & 31.25 & & \\
Corrected total & 79 & 3770 & & & \\
\hline
\end{tabular}

*Significant difference at $p<0.05$. 
14 Antwi-Boasiako and Atta-Obeng

Table 2: Duncans Multiple Range Test for vessel contents for the timber species

(2a)

\begin{tabular}{cccl}
\hline $\begin{array}{l}\text { Duncan } \\
\text { grouping }\end{array}$ & Mean & No. & Timber species \\
\hline A & 16.5 & 20 & A. toxicaria \\
A & 16.25 & 20 & T. ivorensis \\
A & 13.25 & 20 & E. cylindricum \\
B & 8.00 & 20 & M. excelsa \\
\hline
\end{tabular}

$(2 \mathrm{c})$

\begin{tabular}{cccl}
\hline $\begin{array}{l}\text { Duncan } \\
\text { grouping }\end{array}$ & Mean & No. & Radial position \\
\hline $\mathbf{A}$ & 14.875 & 40 & Sapwood \\
B & 12.125 & 40 & Heartwood \\
\hline
\end{tabular}

\begin{tabular}{cccc}
\hline $\begin{array}{c}\text { Duncan } \\
\text { grouping }\end{array}$ & Mean & No. & $\begin{array}{c}\text { Axial } \\
\text { position }\end{array}$ \\
\hline A & 14.75 & 40 & Top \\
B & 12.25 & 40 & Butt \\
\hline
\end{tabular}

Table 3: ANOVA for fibre contents for the timber species

\begin{tabular}{lccccc}
\hline \multicolumn{1}{c}{ Source } & $\begin{array}{c}\text { Degree of } \\
\text { Freedom }\end{array}$ & $\begin{array}{c}\text { Sum of } \\
\text { Squares }\end{array}$ & $\begin{array}{c}\text { Mean } \\
\text { square }\end{array}$ & F-value & Pr $>\mathbf{F}$ \\
\hline Model & 15 & 3970 & 264.667 & 2.70 & 0.0030 \\
Error & 64 & 6280 & 98.125 & & \\
Corrected total & 79 & 10250 & & & \\
\hline
\end{tabular}

*Significant difference at $p<0.05$.

Table 4: Duncans Multiple Range Test for fibre contents for the timber species (4a)

\begin{tabular}{cccl}
\hline $\begin{array}{l}\text { Duncan } \\
\text { grouping }\end{array}$ & Mean & No. & Timber species \\
\hline A & 60.00 & 20 & M. excelsa \\
B & 48.25 & 20 & E. cylindricum \\
B & 48.00 & 20 & T. ivorensis \\
B & 43.75 & 20 & A. toxicaria \\
\hline
\end{tabular}

\begin{tabular}{cccl}
\hline $\begin{array}{l}\text { Duncan } \\
\text { grouping }\end{array}$ & Mean & No. & $\begin{array}{l}\text { Axial } \\
\text { position }\end{array}$ \\
\hline A & 50.875 & 40 & Butt \\
A & 49.125 & 40 & Top
\end{tabular}

$(4 c)$

\begin{tabular}{lccl}
\hline $\begin{array}{l}\text { Duncan } \\
\text { grouping }\end{array}$ & Mean & No. & Radial position \\
\hline A & 50.75 & 40 & Heartwood \\
A & 49.75 & 40 & Sapwood \\
\hline
\end{tabular}

$N B$ : Means with the same letter are not significantly different $(p<0.05)$

Journal of Science and Technology C KNUST December 2009 
along the stem. Its $\mathrm{SG}$ is greater at the butt than at the crown. SGs for heartwood and sapwood at its base are not significantly different $(\mathrm{p}<0.05)$ as well as for those at the crown.

$\mathrm{V}$-F ratio for $A$. toxicaria is greater at the crown than at its butt (Fig. 3). Significant difference $(\mathrm{p}<0.05)$ exists between $\mathrm{V}-\mathrm{F}$ ratios at its butt with the heartwood's being greater than for the sapwood. SG is greater at the butt than at the crown. Significant difference $(p<0.05)$ exists between those at the crown with the sapwood's being greater (Fig. 3).
For T. ivorensis, V-F ratio is least in butt heartwood. The difference between those of the sapwoods and also that of the crown heartwood is not significant $(p<0.05)$. SG is greatest in crown sapwood with no significant difference $(p<0.05)$ between those of the heartwoods and that for the butt sapwood (Fig. 4).

$\mathrm{V}-\mathrm{F}$ ratio for $M$. excelsa at the heartwood is higher at its crown than at the butt (Fig. 5). Sapwood V-F ratio is also higher at the crown than at the butt, however, the difference is not significant $(\mathrm{p}<0.05)$. Moreover, $\mathrm{V}-\mathrm{F}$ ratio at the

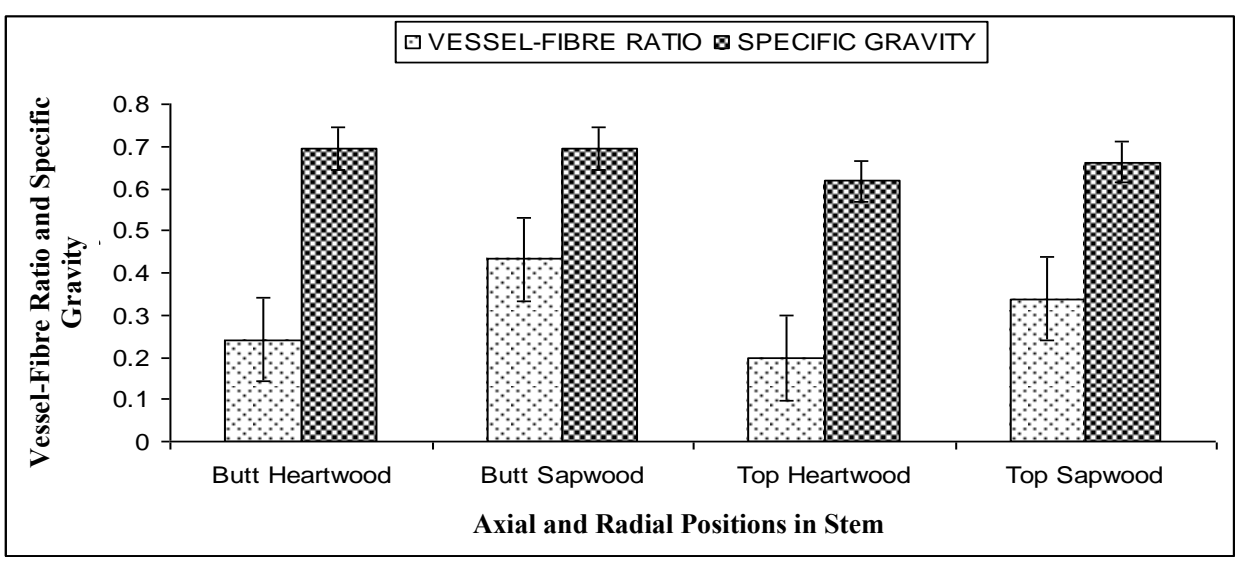

Bars $=$ Standard errors

Fig. 2: Vessel-fibre ratio and specific gravity in E. cylindricum (sapele)

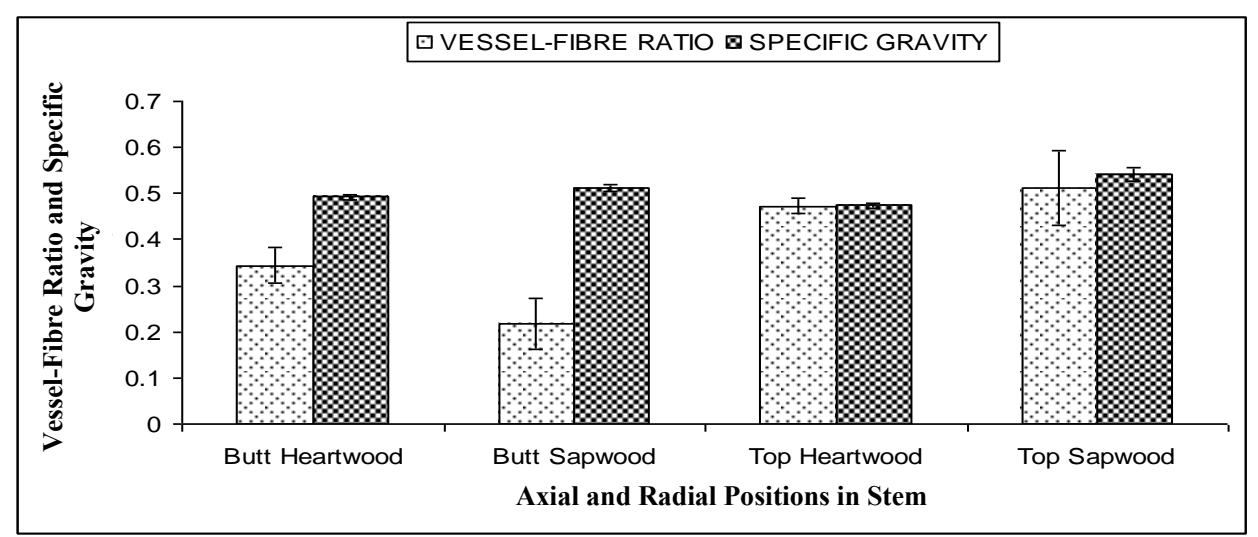

Bars $=$ Standard errors

Fig. 3: Vessel-fibre ratio and specific gravity in $A$. toxicaria (kyenkyen) 
butt is greater in the sapwood than in the heartwood. At the crown, the difference between those in heartwood and sapwood are not significant $(\mathrm{p}<0.05)$. On the contrary, heartwood and sapwood SGs are both higher at the butt than at the crown. At its base, SG is higher in the heartwood than in sapwood; the difference is significant $(\mathrm{p}<0.05)$. At the crown, the sapwood's SG is similar to that for the heartwood. As for the other timbers, as the V-F ratio increases, the less their SGs at every stem position.

\section{Variation in vessel-fibre ratio and specific gravity among the four hardwoods}

Variation between $\mathrm{V}-\mathrm{F}$ ratio and $\mathrm{SG}$ among the four species, presented in Fig. 6, reveals the following respective rankings: $A$. toxicaria $>T$. ivorensis $>$ E. cylindricum $>M$. excelsa, and $M$. excelsa/E. cylindricum $>T$. ivorensis/A. toxicaria. Generally, an increase in the V-F ratio leads to a decrease in the SG of the individual timbers. Table 5 shows significant differences $(\mathrm{p}<0.05)$ between the $\mathrm{V}-\mathrm{F}$ ratios at the various

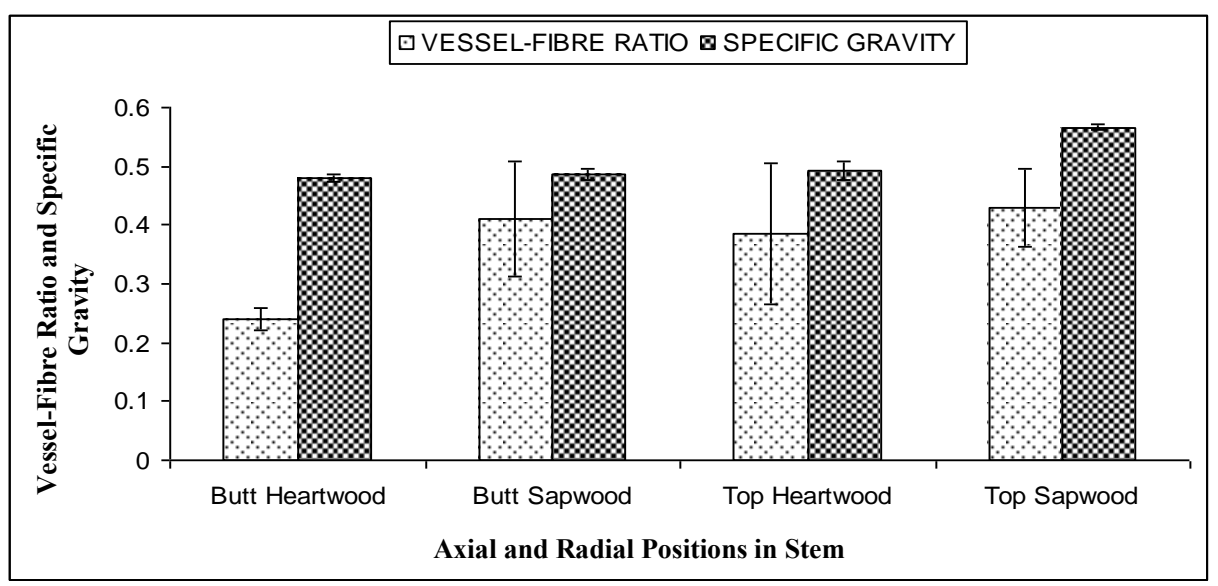

Bars $=$ Standard errors

Fig. 4: Vessel-fibre ratio and specific gravity in $T$. ivorensis (emire)

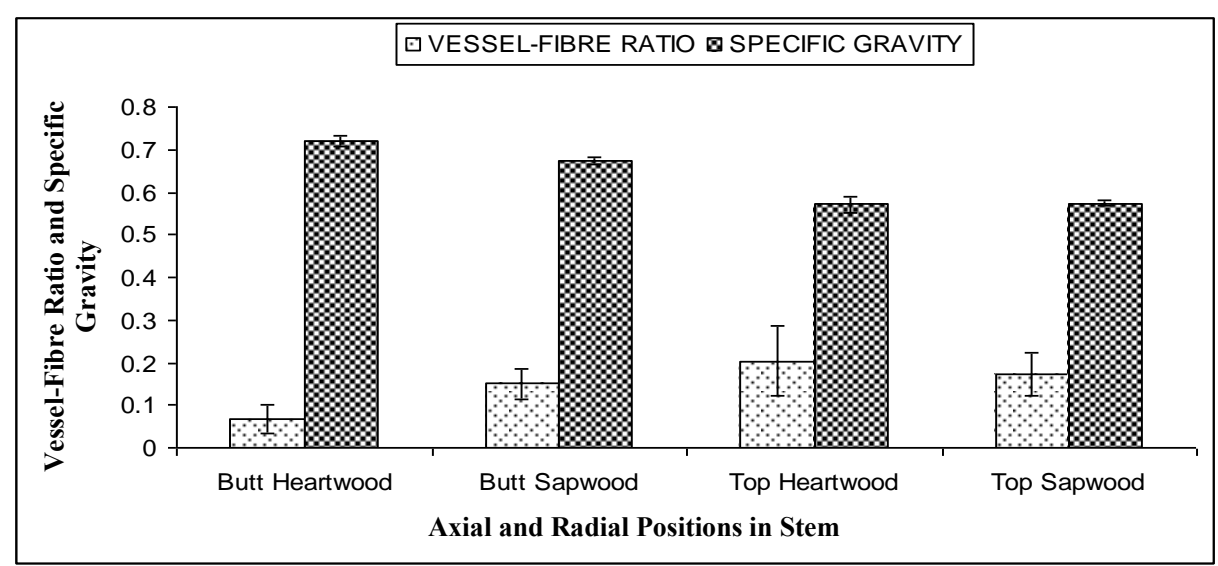

Bars $=$ Standard errors

Fig. 5: Vessel-fibre ratio and specific gravity in M. excelsa (odum) 
stem positions of the timbers. However, differences between those of $A$. toxicaria, T. ivorensis and $E$. cylindricum are not significant $(\mathrm{p}<0.05)$ (Table 6a). Differences exist for $\mathrm{V}-\mathrm{Fs}$ along the boles, that is, between those at the butt and in the crown (Table 6b). However, this is not so across the stems, that is, between those in the heartwood and sapwood (Table 6c). Table 7 also shows significant difference $(p<0.05)$ between SGs of the timbers. However, this is not so between those from $A$. toxicaria and $T$. ivorensis (Table 8a). Differences in SG along the boles are significant $(p<0.05)$ (Table $8 b)$, being greater at the butt than the crown. However, SGs for sapwood and heartwood (i.e. across the stem) are not significantly different $(\mathrm{p}<0.05)$ (Table 8c).
Relationship between vessel-fibre ratio and specific gravity

Linear regression analysis showing the relationship between $\mathrm{V}-\mathrm{F}$ ratio and $\mathrm{SG}$ for the timber species in Table 9 indicates that the increase in $\mathrm{V}-\mathrm{F}$ ratio can only explain $34 \%$ of the variation in $\mathrm{SG}$ for E. cylindricum. $\mathrm{R}^{2}$-value of $34 \%$ shows that the relationship between its V-F ratio and $\mathrm{SG}$ is weak. However, $M$. excelsa had the highest $\mathrm{R}^{2}$-value of $84 \%$, which shows the relationship is the strongest for $\mathrm{V}-\mathrm{F}-\mathrm{SG}$, as compared to $\mathrm{R}^{2}$-values of $32 \%$ and $11 \%$ for the other two timbers ( $T$. ivorensis and $A$. toxicaria) respectively, an indication that the relationship between V-F ratio and SG for the latter species is also not strong, particularly for $A$. toxicaria $\left(\mathrm{R}^{2}=1 \%\right)$.

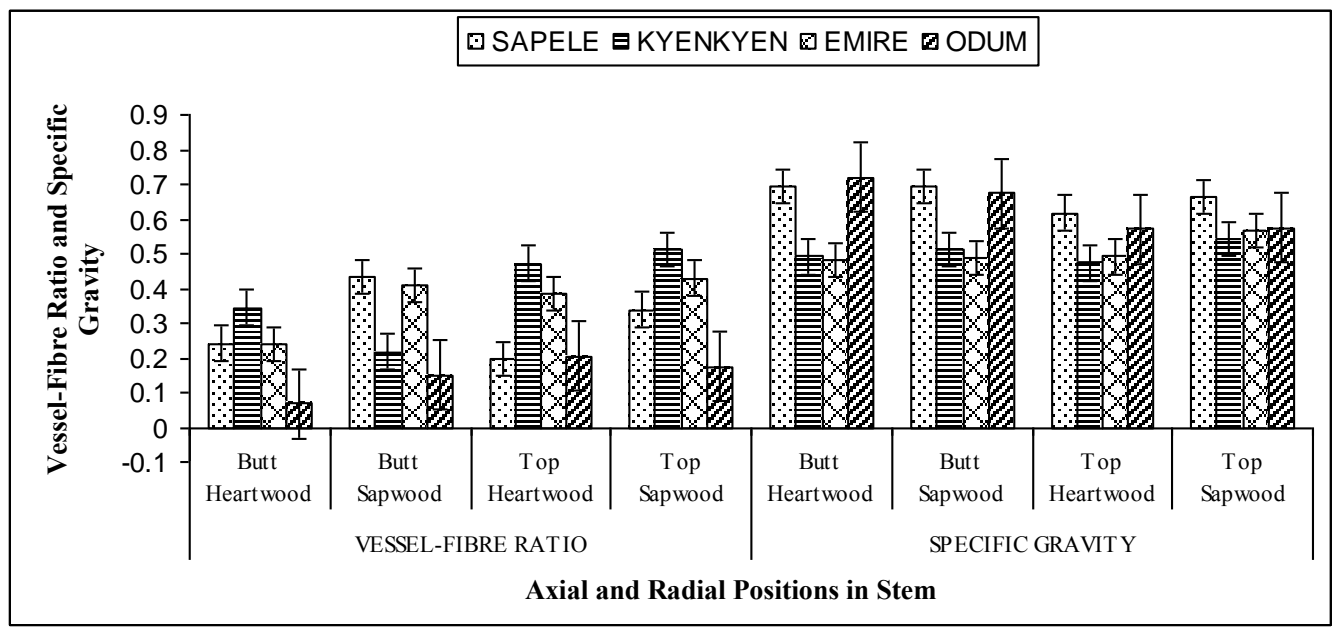

Bars $=$ Standard errors

Fig. 6: Vessel-fibre ratio and specific gravity among the four timber species

Table 5: ANOVA for vessel-fibre ratio for the timber species

\begin{tabular}{lccccc}
\hline \multicolumn{1}{c}{ Source } & $\begin{array}{c}\text { Degree of } \\
\text { Freedom }\end{array}$ & $\begin{array}{c}\text { Sum of } \\
\text { Squares }\end{array}$ & $\begin{array}{c}\text { Mean } \\
\text { square }\end{array}$ & F-value & Pr $>$ F \\
\hline Model & 15 & 1.2860 & 0.08673 & 3.44 & 0.003 \\
Error & 64 & 1.5955 & 0.0249 & & \\
Corrected total & 79 & $2 . .8815$ & & & \\
\hline
\end{tabular}

*Significant difference at $p<0.05$. 
18 Antwi-Boasiako and Atta-Obeng

Table 6: Duncan's Multiple Range Test for vessel-fibre ratio for the timber species

(6a)

\begin{tabular}{cccl}
\hline $\begin{array}{c}\text { Duncan } \\
\text { grouping }\end{array}$ & Mean & No. & \multicolumn{1}{c}{$\begin{array}{c}\text { Timber } \\
\text { species }\end{array}$} \\
\hline $\mathbf{A}$ & 0.3865 & 20 & A. toxicaria \\
$\mathbf{A}$ & 0.3665 & 20 & T. ivorensis \\
$\mathbf{A}$ & 0.3025 & 20 & E. cylindricum \\
B & 0.1490 & 20 & M. excelsa \\
\hline
\end{tabular}

(6b)

\begin{tabular}{cccl}
\hline $\begin{array}{c}\text { Duncan } \\
\text { grouping }\end{array}$ & Mean & No. & $\begin{array}{l}\text { Axial } \\
\text { position }\end{array}$ \\
\hline A & 0.33925 & 40 & Top \\
B & 0.26300 & 40 & Butt \\
\hline
\end{tabular}

$(6 c)$

\begin{tabular}{clcl}
\hline Duncan grouping & Mean & No. & Radial position \\
\hline A & 0.333 & 40 & Sapwood \\
A & 0.2693 & 40 & Heartwood \\
\hline
\end{tabular}

Table 7: ANOVA for specific gravity for the timber species

\begin{tabular}{lccccc}
\hline \multicolumn{1}{c}{ Source } & $\begin{array}{c}\text { Degree of } \\
\text { Freedom }\end{array}$ & $\begin{array}{c}\text { Sum of } \\
\text { Squares }\end{array}$ & $\begin{array}{c}\text { Mean } \\
\text { square }\end{array}$ & F-value & Pr $>$ F \\
\hline Model & 15 & 1.14219 & 0.0761 & 61.91 & $<0.0001$ \\
Error & 144 & 0.17711 & 0.0012 & & \\
Corrected total & 159 & 1.3193 & & & \\
\hline
\end{tabular}

*Significant difference at $p<0.05$.

Table 8: Duncan's Multiple Range Test for Specific gravity for the timber species

(8a)

\begin{tabular}{cccl}
\hline $\begin{array}{c}\text { Duncan's } \\
\text { grouping }\end{array}$ & Mean & No. & $\begin{array}{c}\text { Timber spe- } \\
\text { cies }\end{array}$ \\
\hline A & 0.667 & 40 & E. cylindricum \\
B & 0.635 & 40 & M. excelsa \\
C & 0.507 & 40 & T. ivorensis \\
C & 0.505 & 40 & A. toxicaria \\
\hline
\end{tabular}

(8b)

\begin{tabular}{lccc}
\hline $\begin{array}{l}\text { Duncan's } \\
\text { grouping }\end{array}$ & Mean & No. & $\begin{array}{c}\text { Axial } \\
\text { position }\end{array}$ \\
\hline A & 0.594 & 40 & Butt \\
B & 0.563 & 40 & Top \\
\hline
\end{tabular}

(8c)

\begin{tabular}{cccl}
\hline Duncan's grouping & Mean & No. & Radial position \\
\hline A & 0.588 & 40 & Sapwood \\
A & 0.567 & 40 & Heartwood \\
\hline
\end{tabular}

$N B$ : Means with the same letter are not significantly different $(p<0.05)$. 


\section{DISCUSSION}

All four wood species exhibit the major hardwood cell types, which comprise vessels, fibres and parenchyma (Haygreen and Bowyer, 1996). Their anatomical properties, presented in the photomicrographs (Plates 1-4), are similar to those investigated by other researchers including Oteng-Amoako (2006). Kollman and Côté (1984) and Negi (2004) explained that the main function of the vessels is conduction, particularly of water and mineral nutrients from the soil and through the roots to various parts of the tree, primarily at the crown. Generally, the vessel content is greater at the crown than at the butt and also in the sapwood than in the heartwood (Table 2a-c). Apart from E. cylindricum, whose fibre content is greater at the crown, the other three species have more fibres at the butt than at the crown. However, all the four species have more fibres in the heartwood than in the sapwood (especially at the butt). From the preceding observations, it is realized that the amount of fibres decreases with an increase in vessel content of each timber. Thus, Kollman and Côté (1984) reported a wide variation in the proportion of cell types in hardwoods and found that in a more porous timber such as Tilia americana L., its vessels form as much as $55.6 \%$ of the wood volume, fibres $36.1 \%$ (and parenchyma $8.3 \%$, which is a small amount for hardwood). At the other extreme, they stated that French (1923) observed Hicoria (now Carya) ovata vessels to constitute only $6.5 \%$ of its total volume, fibres $66.5 \%$ [and parenchyma (ca. 28\%)]. Moreover, Panshin and de Zeeuw (1980) reported that poplar (a tropical wood) is dominated by relatively high fibre proportion (53-60\%), followed by vessel elements (28$34 \%$ ) and ray cells (11-14\%). Between the four timbers, $A$. toxicaria possesses the greatest vessel content (16.5\%) then T. ivorensis $(16.25 \%)$, E. cylindricum $(13.25 \%)$ and $M$. excelsa $(8.00 \%)$. Unsurprisingly, fibre content is also greatest in $M$. excelsa $(60 \%)$, followed by $E$. cylindricum (48.25\%), T. ivorensis (48\%) and A. toxicaria $(43.75 \%)$ (Tables $3 \mathrm{a}$ and $4 \mathrm{a})$. It is anticipated the different proportions of these cell types could affect their individual properties, as vessel content could greatly influence wood vessel-to-fibre (V-F) ratio. Expectedly, the timbers have higher $\mathrm{V}-\mathrm{F}$ ratios at their crowns than at their butts and in their sapwoods than in the heartwoods except in E. cylindricum whose V-F ratio was slightly higher in its heartwood. Inter-species variation has also been found to exist among the V-F ratios of these timbers. Thus, A toxicaria, which has the greatest vessel content and the least amount of fi-

Table 9: Regression Analysis for vessel-fibre ratio and specific gravity for the timbers

\begin{tabular}{|c|c|c|c|c|}
\hline Timber species & Stem position & Vessel-fibre ratio & Specific gravity (x1000) & $\mathbf{R}^{2}$ \\
\hline \multirow{4}{*}{ E. cylindricum } & Crown sapwood & 0.34 & 0.66 & \multirow{4}{*}{0.34} \\
\hline & Crown heartwood & 0.20 & 0.62 & \\
\hline & Butt sapwood & 0.43 & 0.69 & \\
\hline & Butt heartwood & 0.24 & 0.70 & \\
\hline \multirow{4}{*}{ M. excelsa } & Crown sapwood & 0.17 & 0.57 & \multirow{4}{*}{0.84} \\
\hline & Crown heartwood & 0.20 & 0.57 & \\
\hline & Butt sapwood & 0.15 & 0.67 & \\
\hline & Butt heartwood & 0.07 & 0.72 & \\
\hline \multirow{4}{*}{ T. ivorensis } & Crown sapwood & 0.43 & 0.57 & \multirow{4}{*}{0.32} \\
\hline & Crown heartwood & 0.39 & 0.49 & \\
\hline & Butt sapwood & 0.41 & 0.49 & \\
\hline & Butt heartwood & 0.24 & 0.48 & \\
\hline \multirow{4}{*}{ A. toxicaria } & Crown sapwood & 0.51 & 0.54 & \multirow{4}{*}{0.01} \\
\hline & Crown heartwood & 0.47 & 0.47 & \\
\hline & Butt sapwood & 0.22 & 0.51 & \\
\hline & Butt heartwood & 0.35 & 0.49 & \\
\hline
\end{tabular}




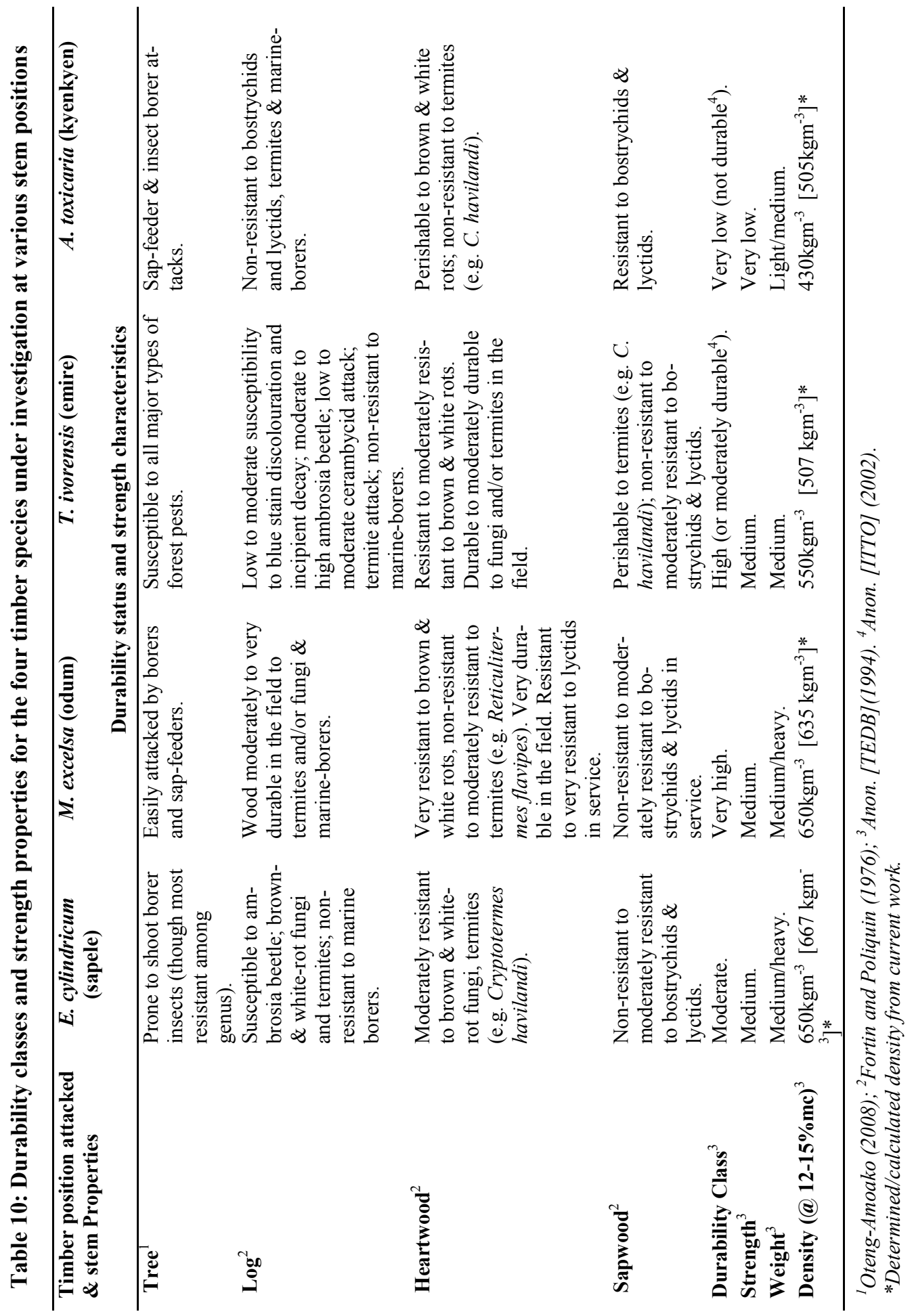

Journal of Science and Technology ㄷ KNUST December 2009 
bres, recorded the highest V-F ratio followed by E. cylindricum, T. ivorensis and then $M$. excelsa; the latter has the least vessel content. Hence, the V-F ratio variability among the timbers can be explained by the differences in the vessel proportion in relation to the fibre content in each species. The present study has therefore contributed to establish that the higher the amount of vessels relative to fibres, the greater the $\mathrm{V}-\mathrm{F}$ ratio, which defines the vessel content in relation to the fibres in the wood. It is also likely that besides the $\mathrm{V}-\mathrm{F}$ ratio, cell type proportions (especially fibre and vessel contents) will influence several other wood characteristics including specific gravity (SG) and durability.

E. cylindricum and $M$. excelsa have higher SGs (667 and $635 \mathrm{kgm}^{-3}$ respectively) than T. ivorensis and $A$. toxicaria $\left(507\right.$ and $505 \mathrm{kgm}^{-3}$ respectively). These do not differ much from their published data (i.e. $650 \mathrm{kgm}^{-3}$ for both E. cylindricum and $M$. excelsa, $550 \mathrm{kgm}^{-3}$ for $T$. ivorensis and $430 \mathrm{kgm}^{-3}$ for $A$. toxicaria) recorded by Anon. (1994). However, with the exception of E. cylindricum, these timbers have the greatest SGs in their butts. This is not unexpected. Antwi-Boasiako (2004) found stem density irregularities in four Ghanaian hardwoods (i.e. Corynanthe pachyceras Welw., Glyphaea brevis (Sprengel) Monachino, Nauclea diderrichii (de Wild.) Merr. and Nesogodornia papaverifera (A. Chev.) R. Capuron.). However, their bases were generally heavier than the middle and crown regions. Moreover, he reported that Luxford (1932) in Brown et al. (1952) found the bases of redwood to be denser than at the crowns, although the trend could change in several other timbers. SG variations among species can be attributed to several factors including stem position and location within the range of species (Haygreen and Bowyer, 1996), which could equally contribute to explain such variability at the crowns and butts of the woods currently under investigation. However, although SGs were slightly greater in their sapwoods than at the heartwoods, the differences are not significant $(\mathrm{p}<0.05)$. Similarly, Panshin and de Zeeuw (1980) reported that SG either tends to be greater in the sapwood or heartwood. While Antwi-Boasiako (2004) asserted that there is always the tendency for density to increase from the outer sapwood (near the bark) to the inner heartwood (near the pith) of the four Ghanaian timbers he studied, which he attributed to many factors including the type and amount of their vessels, fibres, lignin and extractives, Panshin and de Zeeuw (1980) also attributed density variation to differences in the size of cells, cell wall thickness and the interrelationship between the numbers of cells of various kinds. In this regard, Negi (2004) observed that fibres account for a substantial proportion of the weight of the wood. Thus, the amount of fibres possessed by the four species (ranked as: $M$. excelsa $>E$. cylindricum $>T$. ivorensis $>A$. toxicaria) would be expected to influence their respective V-F ratios and SGs as well.

Furthermore, Balatinecz et al. (2001) reported that wood relative density is most influenced by its vessel-to-fibre ratio (as well as the diameter and wall thickness of the fibre and vessel elements). SG among the four species follows the same pattern, while their $\mathrm{V}-\mathrm{F}$ ratios are the complete reverse of the pattern in their fibre contents. Thus, Panshin and de Zeeuw (1980) concluded from several works that wood SG increases with increasing amounts of its fibres; Haygreen and Bowyer (1996) also emphasized that wood SG is directly linked with its porosity (i.e. void volume). Therefore, since SG was highest in $M$. excelsa, followed by $E$. cylindricum, $T$. ivorensis and A. toxicaria, it could be explained that SG among the four timbers decreased with increasing V-F ratio. Of course, linear regression analysis indicates that an increase in the $\mathrm{V}-\mathrm{F}$ ratio can explain $84 \%, 34 \%$, $32 \%$ and $1 \%$ of the variations in SG in the respective SGs of the timbers. Thus, the relationship between $\mathrm{V}-\mathrm{F}$ ratio and $\mathrm{SG}$ is strongest for M. excelsa $\left(\mathrm{R}^{2}=84 \%\right)$, which has the greatest fibre content to have contributed to the great increases in its $\mathrm{SG}$ owing to great variations in its $\mathrm{V}-\mathrm{F}$ ratio. The correlation is weak in the three timbers, especially for $A$. toxicaria $\left(\mathrm{R}^{2}=\right.$ $1 \%$ ), which recorded the least fibres but greatest vessel content. Panshin and de Zeeuw 
(1980) and Negi (2004) have demonstrated that the best determinant of wood SG is the proportion of fibres in its make-up. It therefore connotes that the more fibres relative to vessels in a tree, the stronger the relationship between its $\mathrm{V}-\mathrm{F}$ ratio and SG. However, it should be stressed that other factors (e.g. porosity, moisture content, vessel-lumen diameter, amount of extractives) other than V-F ratio may also contribute to wood SG (Shrivastava, 1987). This could explain why the relationship is weak for E. cylindricum, T. ivorensis and A. toxicaria.

The correlation between V-F ratios, SGs (Table 9) and durability classes (Table 10) of the four timbers might as well be established since the proportion of these cell types could likely influence durability. The presence and amounts of wood fibres affect its mechanical strength (Wilson and White, 1986). Antwi-Boasiako (2004) reported that woods with more vessels (and rays) make it light for easy grazing by termites and other bio-degraders and also form the easiest courts for fungal hyphae to attack more wood cells. Anon. (1994) reported the durabilities for M. excelsa, T. ivorensis, E. cylindricum and $A$. toxicaria as very high, high, moderate and very low respectively. $A$. toxicaria, which has the greatest amount of vessels, least fibre content, greatest $\mathrm{V}-\mathrm{F}$ ratio and least $\mathrm{SG}$, has the weakest $\mathrm{V}-\mathrm{F}$ ratio-SG correlation $\left(\mathrm{R}^{2}=1 \%\right)$ and very low durability. On the other hand, M. excelsa has very high durability due to its smallest amount of vessels but greatest fibre content, least V-F ratio, greatest $\mathrm{SG}$ and strongest V-F ratio-SG relationship $\left(\mathrm{R}^{2}=84 \%\right)$. From the durability of the timbers at their various tree positions, strength and other properties summarized in Table 10, it is anticipated that $E$. cylindricum also has better field performance or service life than $T$. ivorensis. It is therefore unsurprising that Anon. (1994) reported that $A$. toxicaria is endowed with very low strength and light to medium weight, $T$. ivorensis has medium strength and weight, while E. cylindricum and $M$. excelsa have medium strength and medium to heavy weight, which could all be attributed to their various cell type proportions.

\section{CONCLUSION}

Present findings indicate an increase in vessel content result in a relative decrease in wood fibres, which affect other properties. More vessels are recorded at the crowns and in sapwoods of the hardwoods than at their butts and in heartwoods, unlike their fibres. This variability affect their vessel-fibre (V-F) ratios, which are similarly higher at their crowns and sapwoods than at butts and heartwoods. Inter-species variation shows $A$. toxicaria is endowed with the greatest amount of vessels then $T$. ivorensis, E. cylindricum and M. excelsa, while their V-F ratios and corresponding specific gravities (SGs) rank as: A. toxicaria $>E$. cylindricum $>$ T. ivorensis $>M$. excelsa with their SGs generally greatest in the butts. The higher the V-F ratio, the lower the $\mathrm{SG}$ of each timber. Fibre and vessel contents correlate with $\mathrm{V}$-F ratio, SG and durability of each timber. Accordingly, $A$. toxicaria's very low durability class could be associated with its greatest vessel and least fibre contents, thus its greatest $\mathrm{V}-\mathrm{F}$ ratio, least $\mathrm{SG}$ and the weakest $\mathrm{V}-\mathrm{F}$ ratio-SG relationship $\left(\mathrm{R}^{2}=1 \%\right)$ unlike $M$. excelsa's very high durability, strongest $\mathrm{V}-\mathrm{F}$ ratio-SG relationship $\left(\mathrm{R}^{2}=\right.$ $84 \%$ ) and other qualitative constructional properties of this timber besides its durability.

\section{ACKNOWLEDGEMENT}

The authors express their utmost gratitude to Mr Emmanuel Ebanyenle (of Anatomy Laboratory, FORIG) and Mrs. Agnes Ankomah (Biometrician, CRI) all of CSIR, Staff of the Department of Wood Science \& Technology Workshop (KNUST) for their contribution during the execution of the work.

\section{REFERENCES}

Anon. (1989). IAWA List of Microscopic Features for Hardwood Identification. International Association of Wood Anatomist (IAWA) Bulletin 10, 219-332.

Anon. (1994). The Tropical Timbers of Ghana. Timber Export Development Board (TEDB), Takoradi, Ghana; London, UK. $87 \mathrm{pp}$. 
Anon.,(2002). User's Manual for ITTO Tropical Timbers Database. International Tropical Timber Organization [ITTO]. Nagoya University Museum.

Antwi-Boasiako, C. (2004). Assessment of Anatomy, Durability and Treatability of Two Tropical Lesser-Utilized Species and Two Related Primary Species from Ghana. PhD Thesis (2004) submitted to The University of Reading, Reading, England (UK). 319pp.

Balatinecz, J., Kretschmann, E. D. and Leclerq, A. (2001). Achievements in the Utilization of poplar wood. The Forestry Chronicle. Volume 77, No. 22.

Dinwoodie, J. M. (2000). Timber: Its Nature and Behaviour. $2^{\text {nd }}$ ed. $87 \mathrm{pp}$.

Esau, K. 1977. Anatomy of Seed Plants. $2^{\text {nd }}$ ed. John Wiley \& Sons, New York.

Fortin, Y. and Poliquin, J. (1976). Natural Durability and Preservation of One Hundred Tropical African Woods. International Development Research Centre. Ottawa, Canada. 129pp.

Haygreen, J. G. and Bowyer, J. L. (1996). Forest Product and Wood Science: An Introduction. $3^{\text {rd }}$ ed. IOWA State University Press/AMES. 232pp.

Irvine, F. R. (1961). Woody plants of Ghana with special reference to their uses. Oxford Univ. Press, London, UK. 868pp.

Kollman, F. P. and Côté, W. A. Jr. (1984). Principles of Wood Science and Technology. Berlin, Heidelberg, New York. Vol. 1. $10 \mathrm{pp}$.

McDonald, S. S., Williamson, B. G. and Wiemann, M. C. (1995). American Journal of Botany, Vol.82, No.7. (Jul., 1995). Pp. 855 -861 .

Negi, S. S. (2004). Wood Science and Technology. Applied Forestry Series No. 2. International Book Distributors, Dehra Dun, India. 249pp.
Oteng-Amoako, A. A. (2006). 100 Tropical African Timber Trees from Ghana. Tree Description and Wood Identification with Notes on Distribution, Ecology, Silviculture, Ethnobotany and Wood Uses. 304pp.

Panshin, A. J. and de Zeeuw, C. (1980). Textbook of Wood Technology. Structure, Identification, Properties and Uses of the Commercial Woods of the US \& Canada. $4^{\text {th }}$ ed. McGraw-Hill Book Company, New York.

Shrivastava, M. B. (1987). Wood Technology. $1^{\text {st }}$ ed. Pp. $25-28$.

Tsoumis, G. (1991). Science and Technology of Wood: Structure, Properties and Utilization. Van Nostrand Reinhold, New York. 160-174pp.

Weyori, R. (2003). Efficacy of Solignum as a Wood Preservative against Termites. BSc Thesis: Kwame Nkrumah University of Science and Technology. Kumasi.

Whitmore, J. L. (1973). Wood density variation in Costa Rican balsa. Wood Science 5: 223 -229 .

Wiemann, M. C. and Williamson, B. G. (1988). Extreme radial changes in wood specific gravity in some tropical pioneers. Wood and Fibre Science 20: 344-349.

Wiemann, M. C. and Williamson, B. G. (1989). Radial gradients in the specific gravity of wood in some tropical and temperate trees. Forest Science 35: 197-209.

Wiemann, M. C. (1990). Mechanical and Anatomical Characteristics of some Wood of Tropical Pioneer Trees. PhD dissertation, Louisiana State University. Baton Rouge, LA.

Wilson, K. and White, D. J. B. (1986). The Anatomy of Wood: Its Diversity and Variability; Stobart \& Son Ltd. 309pp. 